\title{
42. Türkçe öğretmeni adaylarına göre ideal öğretmen (Muş Alparslan Üniversitesi örneği)
}

\section{Bayram ARICI ${ }^{1}$}

APA: Arıcı, B. (2021). Türkçe öğretmeni adaylarına göre ideal öğretmen (Muş Alparslan Üniversitesi örneği). RumeliDE Dil ve Edebiyat Araştırmaları Dergisi, (22), 678-690. DOI: 10.29000/rumelide.897112.

\section{$\ddot{O} \mathbf{z}$}

Bu araştırma Muş Alparslan Üniversitesi Eğitim Fakültesi Türkçe öğretmenliği programında öğrenim gören öğretmen adaylarının ideal öğretmen algılarını belirlenmek amacıyla yapılmıștır. Araştırma 2020-2021 öğretim yılı güz döneminde yapılmış olup araştırmaya yüz otuz Türkçe öğretmeni adayı gönüllü olarak katılmıştır. Veriler araştırmacının uzman görüşü alarak hazırladığı yarı yapılandırılmış görüşme formu kullanılarak toplanmış elde edilen veriler içerik analizine tabi tutulmuştur. Bulgular kişisel özellikler, mesleki özellikler, iletişim ve örnek alma temalarında toplanmıştır. Temaların altındaki kodlar kişilik özelliklerinde öğrenmeye açık (\% 12,31), anlayışlı (\% 11,54), dost (\% 9,23), idealist (\% 6,92), empatik düşünen (\% 6,15), güvenilen (\% 5,38), neşeli (\% 4,62), adanmış (\%3,85), ahlaklı $(\% 3,08)$, azimli $(\% 3,08)$, değer veren $(\% 3,08)$, demokratik $(\% 3,08)$, dinleyen $(\% 3,08)$, doğru sözlü $(\% 3,08)$, kültürlü $(\% 3,08)$, hoşgörülü $(\% 3,08)$, mütevazı $(\% 3,08)$, özgüven sahibi $(\% 3,08)$, sabırlı $(\% 3,08)$, sevgi dolu $(\% 3,08)$ ve tutarlı $(\% 3,08)$ olarak ortaya çıkmıştır. Mesleki özelliklerde Türkçe öğretmeni adaylarının ifadelerine göre ideal öğretmenin mesleki özellikleri şu kodlardan oluşmuştur: adil (\% 17,69), alanına hâkim (\% 10,77), mesleğini sever (\% 9,23), hayatı öğretir (\% 5,38), disiplinli (\% 5,38), notla tehdit etmez (\% 5,38), donanıml, teknolojiye hâkim $(\% 4,62)$, demokratik $(\% 3,85)$, rehber $(\% 3,85)$, etkili ve verimli ders yapar (\% $3,85)$, sorgulamayı öğretir (\% 3,85), değerleri önemser (\% 3,85), faydalı insan yetiştirir (\% 3,85), fazla yük yüklemez (\% 3,08), firsat verir (\% 3,08), gayretli (\% 3,08), hedefe odaklanır (\% 3,08), hayata hazırlar (\% 3,08), planlı (\% 3,08) olarak ortaya çıkmıștır. Türkçe öğretmeni adaylarının ifadelerine göre ideal öğretmenin örnek alma teması ortaokuldaki Türkçe öğretmeni (\% 9,23), anne (\% 9,23), Atatürk (\% 4,62), lise öğretmeni (\% 3,08) olarak ortaya çıkmıştır. Türkçe öğretmeni adaylarının ifadelerine göre ideal öğretmenin örnek alma teması şu kodlardan oluşmuştur: Ortaokuldaki Türkçe öğretmenim (\% 38, 46), ilkokul öğretmenim (\% 23,o8), annem (\% 18,46), Atatürk $(\%$ 12,31), lisedeki edebiyat öğretmenim $(\%$ 7,69) olarak ortaya çıkmıştır. Türkçe öğretmeni adaylarının öğretmenliğe hazır olma teması hazır (\% 46,15), kendimi geliştirmeliyim (\% 24,62), eksik ve yetersiz (\% 21,54), tedirgin (\% 7,69) olarak ortaya çıkmıştır. Bu araştırmanın Türkçe öğretmeni adaylarına kendilerini ideale daha yakın hissedip daha çok çalışmalarına faydalı olması beklenmektedir.

Anahtar kelimeler: İdeal öğretmen, Türkçe öğretmeni adayları, öğretmen yetiştirme

Dr. Öğr. Üyesi, Muş Alparslan Üniversitesi, Eğitim Fakültesi, Türkçe ve Sosyal Bilimler Eğitimi Bölümü, Türkçe Eğitimi ABD (Muş, Türkiye) b.arici@alparslan.edu.tr, ORCID: 00oo-0001-7213-1331 [Araştırma makalesi, Makale kayıt tarihi: 08.02.2021-kabul tarihi: 20.03.2021; DOI: 10.29000/rumelide.897112]

Adres $\mid$ Address

RumeliDE Dil ve Edebiyat Araşttrmalar Dergisi $\quad$ RumeliDE Journal of Language and Literature Studies Osmanağa Mahallesi, Mürver Çiçeği Sokak, No:14/8 $\quad$ Osmanağa Mahallesi, Mürver Çiçeği Sokak, No:14/8

Kadıköy - İSTANBUL / TÜRKIYE 34714 Kadıköy - ISTANBUL / TURKEY 34714 e-posta: editor@rumelide.com e-mail: editor@rumelide.com

tel: +90 505 7958124, +90 2167730616 phone: +90 505 7958124, +90 2167730616 


\title{
Ideal teacher according to Turkish teacher candidates (Example of Muş Alparslan University)
}

\begin{abstract}
This research was conducted in order to determine the ideal teacher perceptions of pre-service teachers studying at Muş Alparslan University Education Faculty Turkish Language Teaching Program. The research was conducted in the fall semester of the 2020-2021 academic year, and one hundred and thirty Turkish teacher candidates participated in the study voluntarily. The data were collected using a semi-structured interview form prepared by the researcher with expert opinion, and the data obtained were subjected to content analysis. Findings were collected under the themes of personal characteristics, professional characteristics, communication and sampling. Codes under the themes are open to learning (12.31\%), understanding (11.54\%), friendly (9.23\%), idealistic (6.92\%), empathetic (6.15\%), trusted (\%). 5.38), cheerful (4.62\%), devoted (3.85\%), moral (3.08\%), determined (3.08\%), valuing (3.08\%), democratic (3\%, 08), listening (3.08\%), straightforward (3.08\%), cultured (3.08\%), tolerant (3.08\%), modest (3.08\%), self-confident (3\% , o8), patient (3.08\%), loving (3.08\%) and consistent (3.08\%). According to the statements of the Turkish teacher candidates in terms of professional characteristics, the professional characteristics of the ideal teacher consisted of the following codes: fair (17.69\%), dominant in the field (10.77\%), loves his profession (9.23\%), teaches life (5.38\%), disciplined (5.38\%), does not threaten with grades (5.38\%), equipped, technology (4.62\%), democratic (3.85\%), guide (3.85\%), effective and efficient (3.85\%), teaches questioning (3.85\%), cares about values (3.85\%), educates useful people (3.85\%), does not overload (3.08\%), gives opportunity ( $3 \%$ o8), diligent (3.08\%), focused on the target (3.08\%), ready for life $(3.08 \%)$, planned (3.08\%). According to the statements of the Turkish teacher candidates, the ideal teacher sampling theme emerged as secondary school Turkish teacher (9.23\%), mother (9.23\%), Atatürk (4.62\%), high school teacher (3.08\%). According to the statements of the Turkish teacher candidates, the ideal teacher sampling theme consisted of the following codes: My secondary school Turkish teacher (38.46\%), my primary school teacher (23.08\%), my mother (18.46\%), Atatürk (12.31\%), emerged as my literature teacher (7.69\%). The theme of Turkish teacher candidates to be ready for teaching was found to be ready (46.15\%), I have to improve myself (24.62\%), incomplete and inadequate (21.54\%), and anxious (7.69\%). It is expected that this research will help prospective Turkish teachers feel closer to the ideal and work harder.
\end{abstract}

Keywords: Ideal teacher, Turkish teacher candidates, teacher training

\section{Giriş}

Öğrenme, bireyin yaşamında iz bırakan, onun hayata uyum sağlamasında ektili olan davranış değişiklikleridir. Öğrenme, davranışlarda veya öğrenilmiş şekilde davranabilme kapasitesindeki sürekli ve kalıcı değişiklikler (Cevizci, 2010, s.383), beynin aldığı bilgileri sınıflandırıp saklayarak birleştirmesi (Vassaf, 2011) olarak tanımlanmaktadır. Öğrenme karmaşık ve daha etkili tepki göstermeyi sağlar (Ada ve Küçükali, 2016, s.18). Öğretme ise bireyin kendi yaşantısı ve içinde yaşadığı toplumun yaşantısını kaliteli hale getirmek için gerçekleştirilen etkinliklerin tümü (Şahin, 2011), öğrenilmesi planlanan etkinliklerin gerçekleştirilmesi işi (Sünbül, 1996), davranış değişikliğinin okulda planlı ve programlı bir şekilde yapılma süreci (Demirel, 2004, s.9), öğrenmeyi gerçekleştirmek için yapılan etkinliklerin tümü (Yılmaz ve Sünbül, 2003) olarak tanımlanabilir.

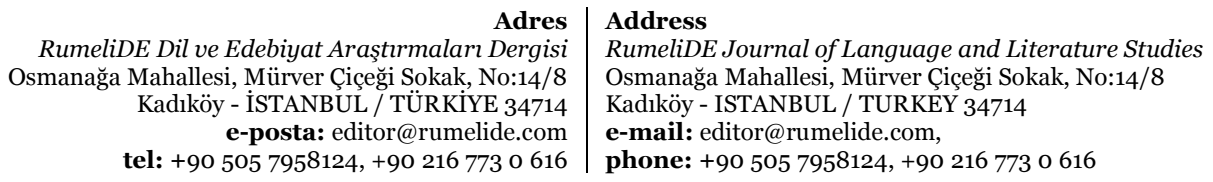


Anne karnındaki bebeğin de öğrenmeye başladığı bilinmekte ve bu öğrenme yaşam boyu sürmektedir. Birey öğrenme sürecinde ilk olarak annesinden bir şeyler öğrenmeye başlayıp öğrenim gördüğü okullarda da öğretmenlerden bir şeyler öğrenir. Öğretmenlik mesleği her şeyden önce sevgi ve hoşgörünün ifade edildiği bir meslektir. Kendisine emanet edilen çocuklara öğretilmesi gereken bilgi ve erdemleri öğretin öğretmen bütün toplumlarda önemli bir yere sahiptir. Öğretmen, eğitim ortamında öğrencilere istendik davranışları kazandıran uzman birey (Sönmez, 2011, s.27), insan mimarı ve insanın kişiliğini biçimlendiren bir sanatkâr (Şişman, 2008, s.192), tarihte ilk görülen eğitim iş göreni (Başaran, 2008, s.181), mesleği bilgi öğretmek olan kimse (TDK, 2021) olarak tanımlanmaktadır.

Türkiye'de de öğretmenlik meslek kanunu çıkarılmamış olmasına rağmen Milli Eğitim Temel Kanunun 43. maddesiyle öğretmenlik mesleği tanımlanmıştır. İlgili maddede öğretmenlik, devletin eğitim, öğretim ve bununla ilgili yönetim görevlerini üzerine alan özel bir ihtisas mesleği (MEB, 1973) olarak tanımlanmıştır. Öğretmenler görevlerini Türk Milli Eğitiminin amaçlarına ve temel ilkelerine uygun olarak yürütmektedirler. Öğretmenlik mesleğine hazırlı genel kültür, özel alan eğitimi ve pedagojik formasyon ile sağlanmaktadır. Öğretmen adaylarının yukarıda belirtilen nitelikleri kazanabilmeleri için, hangi öğretim kademesinde olurlarsa olsunlar yüksek öğrenim görmeleri gerekmektedir. Eğitim sisteminin amacına uygun öğrenciler yetiştirebilmesi için öğretmenin öğrencileri, meslektaşları, okul yönetimi ve veliler ile olan ilişkisiyle mesleki gelişimi (Özden, 2011, s.15) konusunda başarılı olması beklenmektedir. Ancak öğretmen sadece bilgi aktaran, beceri kazandıran değil aynı zamanda faziletli olmayı öğreten, güzel ahlak timsali kimsedir (Çelikkaya, 2016, s.8). Öğretmenlerin yukarıda sıralanan özelliklerden daha fazlasına sahip olmaları gerekmektedir. Bunun için de öğretmenlerin donanımlı olarak yetiştirilmesi şarttır. Öğretmen yetiştirme meselesi bütün ülkelerde ulusal ve uluslar arası boyutta çeşitli araştırmaların ve toplantıların yapıldığı, raporların hazırlandığı bir konu (Şişman, 2009, s.67) olarak görülmektedir. Türkiye'de öğretmen yetiştirme çabaları 16 Mart 1848'de öğretmen okullarının kuruluşundan itibaren başlamış, öğretmen yetiştirme sorumluluğunun YÖK'e devredildiği 1982 yllına kadar önemli çalışmalar yapılmış olmasına rağmen öğretmen yetiştirme sisteminde iç tutarlığa sahip bir politika ve eğitim felsefesi tutturulamadığı söylenebilir (Yapıcı ve Yapıcı, 2004, s.54). 1982 yllından günümüze kadar geçen süreçte öğretmen yetiştirme lisans programlarıyla ilgili olarak; 1997, 2006 ve 2009 yıllarında yeniden düzenleme çalışmaları yapılmıştır. Ancak en kapsamlı çalışma 1996-1997 yıllarında Milli Eğitimi Geliştirme Projesi kapsamında gerçekleştirilmiştir. 19971998 öğretim yılında sekiz yıllık zorunlu eğitime geçilmesi nedeniyle okul kademelerinin ilköğretim ve ortaöğretim olarak düzenlenmesinin ardından Milli Eğitim Bakanlığı (MEB) ve Yükseköğretim Kurulu (YÖK) işbirliğiyle yapılan çalışmalar sonucunda, eğitim/eğitim bilimleri fakültelerindeki bölüm ve anabilim dallarıyla ders programları yeniden oluşturulmuştur (YÖK, 2018, s.9). İdeal kelimesi düşüncenin tasarlayabileceği bütün üstün nitelikleri kendinde toplayan (TDK, 2021) anlamındadır. İdeal öğretmen ise kısaca üstün öğretmen, en nitelikli öğretmen anlamlarında kullanılmaktadır. Öğretmenlerin nitelikleri daha çok yetiştirilmeleriyle ilgilidir. Öğretmenlerde bulunması gereken özelliklerin belirlenmesi ve eğitim alanındaki yeni gelişmelerin takip edilebilmesi için Milli Eğitim Bakanlığı tarafından öğretmenlik mesleği genel yeterlilikleri paydaşların da görüşleri alınarak güncellenmiş olup aşağıdaki tabloda gösterilmiş̧ir (MEB, 2017, s.8).

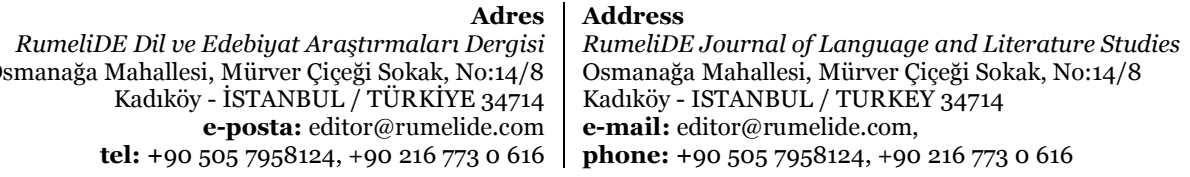

RumeliDE Dil ve Edebiyat Araştırmaları Dergisi tel: +90 $5057958124,+902167730616$
Address

Osmană̆a Maul

e-mail: editor@rumelide.com

phone: +90 505 7958124, +90 2167730616 
Tablo 1. Öğretmenlik mesleği genel yeterlilikleri

\begin{tabular}{|c|c|c|}
\hline Meslek Bilgisi & Mesleki Beceri & Tutum ve Değerler \\
\hline A1. Alan Bilgisi & B1. Eğitim Öğretimi Planlama & $\begin{array}{l}\text { C1. Millî, Manevi ve Evrensel } \\
\text { değerler }\end{array}$ \\
\hline $\begin{array}{l}\text { Alanında sorgulayıcı bakış açısını } \\
\text { bakış açısını kapsayacak şekilde } \\
\text { ileri düzeyde kuramsal, } \\
\text { metodolojik ve olgusal bilgiye } \\
\text { sahiptir. }\end{array}$ & $\begin{array}{l}\text { Ĕ̆gitim öğretim süreçlerini etkin bir } \\
\text { şekilde planlar. }\end{array}$ & $\begin{array}{l}\text { Millî, manevi ve evrensel değerleri } \\
\text { gözetir. }\end{array}$ \\
\hline A2. Alan Ĕ̆itimi Bilgisi & $\begin{array}{l}\text { B2. Öğrenme Ortamları } \\
\text { Oluşturma }\end{array}$ & C2. Öğrenciye Yaklaşım \\
\hline $\begin{array}{l}\text { Alanın öğretim programına ve } \\
\text { pedagojik alan bilgisine hâkimdir. }\end{array}$ & $\begin{array}{l}\text { Bütün öğrenciler için etkili öğrenmenin } \\
\text { gerçekleşebileceği sağlıklı ve güvenli } \\
\text { öğrenme ortamları ile uygun öğretim } \\
\text { materyalleri hazırlar. }\end{array}$ & $\begin{array}{l}\text { Ö̈̆grencilerin gelişimini } \\
\text { destekleyici tutum sergiler. }\end{array}$ \\
\hline A3. Mevzuat Bilgisi & $\begin{array}{l}\text { B3. Öğretme ve Öğrenme } \\
\text { Sürecini Yönetme }\end{array}$ & C3. İletişim ve İş Birliği \\
\hline \multirow{3}{*}{$\begin{array}{l}\text { Birey ve öğretmen olarak görev, } \\
\text { hak ve sorumluluklarına ilişkin } \\
\text { mevzuata uygun davranır. }\end{array}$} & $\begin{array}{l}\text { Öğretme ve öğrenme sürecini etkili bir } \\
\text { şekilde yürütür. }\end{array}$ & $\begin{array}{l}\text { Öğrenci, meslektaş, aile ve } \\
\text { eğitimin diğer paydaşları ile etkili } \\
\text { iletişim ve iş birliği kurar. }\end{array}$ \\
\hline & B4. Ölçme ve Değerlendirme & C3. Kişisel ve Mesleki Gelişim \\
\hline & $\begin{array}{l}\text { Ölçme ve değerlendirme, yöntem, } \\
\text { teknik ve araçlarını amacına uygun } \\
\text { kullanır. }\end{array}$ & $\begin{array}{l}\text { Öz değerlendirme yaparak kişisel } \\
\text { ve mesleki gelişimine yönelik } \\
\text { çalışmalara katılır. }\end{array}$ \\
\hline
\end{tabular}

Tablo 1'e göre öğretmenlerden meslek bilgisi (alan bilgisi, alan eğitimi bilgisi ve mevzuat bilgisi), mesleki beceriler (eğitim öğretimi planlama, öğrenme ortamları oluşturma, öğretme ve öğrenme sürecini yönetme ve ölçme ve değerlendirme), tutum ve değerler (millî, manevi ve evrensel değerler, öğrenciye yaklaşım, iletişim ve iş birliği) ve kişisel ve mesleki gelişim konularında yeterli olmaları istenmektedir. Öğretmen adaylarının da bu yeterliliklere sahip olarak yetiştirilmeleri ve öğretmen olarak atandıklarında mesleğe daha kolay uyum sağlamalarına katkıda bulunacaktır. Toplumun eğitim kurumlarından ve öğretmenlerden beklentilerinin artması, eğitim sistemi içinde öğretmenlerin rollerinin farklılaşmasını ve öğretmen yetiştirmenin önemini de arttırmaktadır (Temizkan, 2008, s.463). Öğretmenlerin kalitelerinin artması eğitim kurumlarının kalitelerinin de artmasını sağlayacak olup bu bağlamda öğretmen yetiştirmeye gereken önemin verilmesi (Yanpar Yelken, Çelikkaleli ve Çapri, 2007, s.194), öğretmen yetiştirme sürecinde öğretmenlerin sahip olması gereken niteliklere uygun öğretim ve uygulamaların yapılması kaçınılmazdır (Maden, Durukan ve Aslan, 2010, s.1368). Öğretmen adaylarının yakın gelecekte öğretmen olarak atanma ihtimalleri bulunduğu için ideal öğretmen algıları büyük önem taşımaktadır. Öğretmen adaylarının öğretmenlik mesleğine karşı algıları mesleklerini nasıl gerçekleştireceklerini ve buna bağlı olarak nasıl öğrenciler yetiştireceklerini etkileyip (Atabek Yiğit ve Balkan Kıyıcı, 2019, s.21) ideal ya da ideale yakın öğretmenler olarak yetişmeleri de toplumsal hayata olumlu yön verilmesini sağlayacaktır.

\section{Yöntem ve amaç}

Bu araştırma, Muş Alparslan Üniversitesi Eğitim Fakültesi Türkçe öğretmenliği programında öğrenim gören Türkçe öğretmeni adaylarının ideal öğretmen algılarını ortaya koyarak onlarda bu bağlamda bir bilinç oluşmasına katkıda bulunmak amacıyla yapılmıştır.

RumeliDE Dil ve Edebiyat Araştirmaları Dergisi Osmanağa Mahallesi, Mürver Ciçeği Sokak, No:14/8 Kadıköy - ÍSTANBUL / TÜRKIYE 34714 e-posta: editor@rumelide.com tel: +90 $5057958124,+902167730616$
Address

RumeliDE Journal of Language and Literature Studies

Osmanağa Mahallesi, Mürver Çiçeği Sokak, No:14/8

Kadıköy - ISTANBUL / TURKEY 34714

e-mail: editor@rumelide.com,

phone: +90 $5057958124,+902167730616$ 


\section{Problem}

Türkçe öğretmeni adaylarının ideal öğretmen algıları nasıldır?

Bu probleme bağlı olarak aşağıdaki alt problemlere de cevap aranmıştır:

1) Sizce ideal öğretmenin özellikleri nelerdir?

2) Size göre ideal öğretmen kimdir?

3) Kendinizi öğretmenliğe hazır görüp/görmemenize ilişkin düşüncelerinizi nedenleriyle birlikte belirtiniz.

\section{Yöntem}

Betimsel analiz ve görüşme yönteminin kullanıldığı bu araştırmada araştırmacının hazırladığı yarı yapılandırılmış görüşme formuyla veriler toplanmıştır. Betimsel araştırmalar, araştırmacının ele aldığı bir olayı tanımlamak ya da çalışılan örneklemle ilgili gerçek ve tam tanımlama yapmak için kullanılan bir araştırma türüdür (Hocaoğlu ve Baysal, 2019, s.73). Öğretmen adaylarına kişisel bilgi formuna ek olarak üç sorunun yer aldığı yarı yapılandırılmış görüşme formu Google formlar ile uygulanmış, görüşmeler içerik analiziyle açık kodlama yapılarak çözümlenmiştir. Görüşme, araştırmaya katılanların belli bir konudaki duygu ve düşüncelerini alma etkinliği (Sönmez ve Alacapınar, 2019, s.187), düşüncelerin açığa çıkarılması (Karagöz, 2017, s.577), derinlemesine bilgi sağlanmasıdır (Büyüköztürk vd., 2019, s. 158).

\section{Çalışma grubu}

Bu çalışmaya 2020-2021öğretim yll güz döneminde Muş Alparslan Üniversitesi Eğitim Fakültesi Türkçe öğretmenliği programında öğrenim gören yüz otuz Türkçe öğretmeni adayı gönüllü olarak katılmıştır. Öğretmen adaylarının özellikleri aşağıda Tablo 2'de gösterilmiştir.

Tablo 2. Araştırmaya katılan öğretmen adaylarının özellikleri

\begin{tabular}{lllll}
\hline Cinsiyet/ Sinıf & 1.sınıf & 2.sınıf & 3.sınıf & 4.Sınıf \\
Erkek & 11 & 8 & 11 & 14 \\
Kadın & 35 & 18 & 16 & 17 \\
Toplam & 46 & 26 & 27 & 31 \\
\hline
\end{tabular}

Tablo 2'ye göre araştırmaya 46 birinci sınıfta, 26 ikinci sınıfta, 27 üçüncü sınıfta ve 31 dördüncü sınıfta öğrenim gören toplam yüz otuz Türkçe öğretmeni adayı gönüllü olarak katılmıştır.

\section{Verilerin toplanması ve analizi}

Araştırmada Muş Alparslan Üniversitesi Eğitim Fakültesi Türkçe öğretmenliği programı öğrencilerine "Sizce ideal öğretmenin özellikleri nelerdir?", "Size göre ideal öğretmen kimdir?" ve "Kendinizi öğretmenliğe hazır görüp/görmemenize ilişkin düşüncelerinizi nedenleriyle birlikte belirtiniz." Açık uçlu sorularının yanında cinsiyet ve sınıflarının sorulduğu görüşme formu uygulanıp öğrencilerin gönüllülük esasına göre bu forma cevap vermeleri istenmiştir. Görüşme formundaki açık uçlu soruların araştırmaya uygun olup olmadığına ilişkin uzman görüşleri alınmış, soruların içerik-kapsam

\begin{tabular}{|c|c|}
\hline & \\
\hline eliDE Dil ve Edebiyat Araşttrmaları De & E Journal of Language and Literature Studies \\
\hline 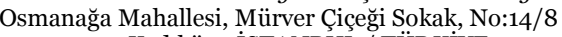 & Mahallesi, Mürver Çiçeği Sokak, No:14/8 \\
\hline Kadıköy $-\mathrm{I}$ & ISTANBUL / TURKEY 34714 \\
\hline $\begin{array}{r}\text { e-posta: editor } \\
\text { tel: }+905057958124,+9\end{array}$ & $\begin{array}{l}\text { editor@rumelide.com, } \\
\text { +90 505 7958124, +90 } 2167730616\end{array}$ \\
\hline
\end{tabular}


geçerlikleri uzman görüşü ile sağlanmıştır. 130 öğrenci araştırma sorularına cevap vermiş, alınan cevaplar içerik analizi ile analiz edilmiştir. Analiz sürecinde elde edilen veriler kodlanıp öğretmen adaylarının ifadeleri bazı temalar altında toplanmıştır. Araştırmada elde edilen veriler öğretmen adaylarının ifadelerinden direkt alıntı yapılarak desteklenmiştir. Bu aşamada direkt alıntı yapılırken her öğretmen adayına kod verilmiş (EÖ1: Erkek öğretmen 1), katılımcıların kimlikleri gizli tutulmuştur. Analiz işleminin sonunda ise uzmanlardan gelen kodlarla öğretmen adaylarının ifadeleri incelenmiş, uzmanların görüş birliğinde oldukları tespit edilmiştir.

\section{Bulgular}

Türkçe öğretmeni adayların ilgili sorulara verdikleri yanıtlardan oluşturulan temalar, kodlar ve frekans dağılımları ile sunulmuş, görüşlerinden doğrudan alıntılar yapılarak yorumlanmaya çalışılmıştır.

Veriler analiz edildiğinde Türkçe öğretmeni adaylarından elde edilen bulgulardan kişilik özellikleri temasına ilişkin kodlar Tablo 3'te gösterilmiştir.

Tablo 3. İdeal öğretmenin kişilik özellikleri temasına ilişkin kodlar

\begin{tabular}{llll}
\hline Tema Kodlar & f & \% \\
öğrenmeye açlk & 16 & 12,31 \\
anlayışlı & 15 & 11,54 \\
dost & 12 & 9,23 \\
idealist & 9 & 6,92 \\
empatik düşünen & 8 & 6,15 \\
güvenilen & 7 & 5,38 \\
neşeli & 6 & 4,62 \\
adanmış & 5 & 3,85 \\
Kişisel Özellikler & ahlâklı & 4 & 3,08 \\
& azimli & 4 & 3,08 \\
değer veren & 4 & 3,08 \\
demokratik & 4 & 3,08 \\
dinleyen & 4 & 3,08 \\
doğru sözlü & 4 & 3,08 \\
kültürlü & 4 & 3,08 \\
hoşgörülü & 4 & 3,08 \\
mütevazı & 4 & 3,08 \\
özgüven sahibi & 4 & 3,08 \\
sabırlı & 4 & 3,08 \\
sevgi dolu & 4 & 3,08 \\
tutarlı & 4 & 3,08 \\
\hline & &
\end{tabular}

Türkçe öğretmeni adaylarının ifadelerine göre ideal öğretmenin kişilik özellikleri şu kodlardan oluşmuştur: öğrenmeye açık (\% 12,31), anlayışlı (\% 11,54), dost (\% 9,23), idealist (\% 6,92), empatik

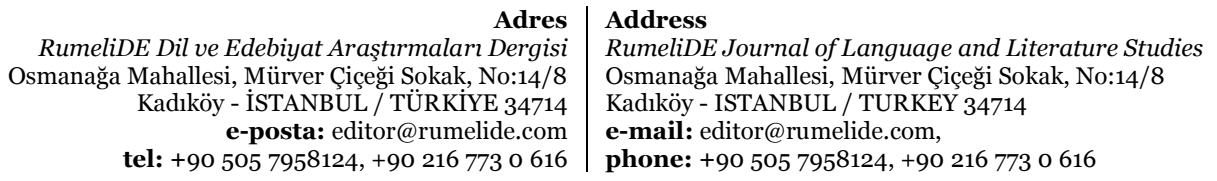


düşünen (\% 6,15), güvenilen (\% 5,38), neşeli (\% 4,62), adanmış $(\% 3,85)$, ahlaklı $(\% 3,08)$, azimli $(\% 3,08)$, değer veren $(\% 3,08)$, demokratik $(\% 3,08)$, dinleyen $(\% 3,08)$, doğru sözlü $(\% 3,08)$, kültürlü $(\% 3,08)$, hoşgörülü $(\% 3,08)$, mütevazı $(\% 3,08)$, özgüven sahibi $(\% 3,08)$, sabırlı $(\% 3,08)$, sevgi dolu $(\% 3,08)$ ve tutarlı $(\% 3,08)$ olarak ortaya çıkmıştır.

Türkçe öğretmeni adaylarının ideal öğretmenin kişilik özelliklerine ilişkin bazı ifadeleri aşağıda verilmiştir:

İdeal öğretmen, alanında kendini geliştirmiş, öğrenmeye açık olan, eleştirilere saygı duyan ve özeleştiri yapabilen, bir öğrencinin büyük değissimler yaratabilecek yetkinliğe sahip olduğunu bilen kişidir (ÖE1).

İdeal öğretmen, anlayışh olan, ayrtm yapmayan ve asla öğrenciyi küçük düşürmeyen öğretmendir (ÖK1).

İdeal öğretmen, anlayışh, hoşgörülü, samimi olmahdır (ÖE2).

İdeal öğretmen, öğrenci dostudur (ÖE3).

İdeal öğretmen; mesleğini severek yapan, amacı öğrenmek, öğretmek olan ve kendisinin de bu yoldan geçtiğini düşünerek empati duygusuyla hareket eden eğitimcidir (ÖK2).

Empati kurmasını bilen, özverili, dersini seven sevdiren, fedakâr olandır (ÖK3).

Türkçe öğretmeni adaylarından elde edilen bulgulardan mesleki özellikler temasına ilişkin kodlar Tablo 4'te gösterilmiştir.

Tablo 4. İdeal öğretmenin mesleki özellikleri temasına ilişkin kodlar

\begin{tabular}{|c|c|c|c|}
\hline \multirow[t]{8}{*}{ Tema } & \multicolumn{2}{|l|}{ Kodlar } & $\%$ \\
\hline & \multicolumn{2}{|l|}{ adil } & 17,69 \\
\hline & \multicolumn{2}{|l|}{ alanına hakim } & 10,77 \\
\hline & \multicolumn{2}{|l|}{ mesleğini sever } & 9,23 \\
\hline & \multicolumn{2}{|l|}{ hayatı öğretir } & 5,38 \\
\hline & \multicolumn{2}{|l|}{ disiplinli } & 5,38 \\
\hline & \multicolumn{2}{|l|}{ notla tehdit etmez } & 5,38 \\
\hline & \multicolumn{2}{|l|}{ donanımlı, teknolojiye hakim } & 4,62 \\
\hline \multirow{9}{*}{ Mesleki özellikler } & \multicolumn{2}{|l|}{ demokratik } & 3,85 \\
\hline & \multicolumn{2}{|l|}{ rehber } & 3,85 \\
\hline & \multicolumn{2}{|l|}{ etkili ve verimli ders yapar } & 3,85 \\
\hline & \multicolumn{2}{|l|}{ sorgulamayı öğretir } & 3,85 \\
\hline & \multicolumn{2}{|l|}{ değerleri önemser } & 3,85 \\
\hline & \multicolumn{2}{|l|}{ faydalı insan yetiştirir } & 3,85 \\
\hline & \multicolumn{2}{|l|}{ fazla yük vermez } & 3,08 \\
\hline & \multicolumn{2}{|l|}{ firsat verir } & 3,08 \\
\hline & \multicolumn{2}{|l|}{ gayretli } & 3,08 \\
\hline $\begin{array}{r}\text { Rumeli } \\
\text { Osmanağa }\end{array}$ & $\begin{array}{r}\text { Adres } \\
\text { Dil ve Edebiyat Arassttrmaları Dergisi } \\
\text { ahallesi, Mürver Ciçeği Sokak, No:14/8 } \\
\text { Kadıköy - İSTANBUL / TÜRKiYE } 34714 \\
\text { e-posta: editor@rumelide.com } \\
\text { l: +90 505 7958124, +90 } 216773 \text { o } 616\end{array}$ & $\begin{array}{l}\text { Address } \\
\text { RumeliDE Journal of Languag } \\
\text { Osmanağa Mahallesi, Mürver C } \\
\text { Kadlköy - ISTANBUL / TURKE } \\
\text { e-mail: editor@rumelide.com, } \\
\text { phone: +90 505 7958124, +90 }\end{array}$ & $\begin{array}{l}\text { tudies } \\
\text { /8 }\end{array}$ \\
\hline
\end{tabular}




$\begin{array}{lcc}\text { hedefe odaklanır } & 4 & 3,08 \\ \text { hayata hazırlar } & 4 & 3,08 \\ \text { planlı } & 4 & 3,08\end{array}$

Türkçe öğretmeni adaylarının ifadelerine göre ideal öğretmenin mesleki özellikleri şu kodlardan oluşmuş̧tur: adil (\% 17,69), alanına hâkim (\% 10,77), mesleğini sever (\% 9,23), hayatı öğretir (\% 5,38), disiplinli (\% 5,38), notla tehdit etmez (\% 5,38), donanımll, teknolojiye hakim (\% 4,62), demokratik (\% $3,85)$, rehber (\% 3,85), etkili ve verimli ders yapar (\% 3,85), sorgulamayı öğretir (\% 3,85), değerleri önemser (\% 3,85), faydalı insan yetiştirir (\% 3,85), fazla yük yüklemez (\% 3,08), firsat verir $(\% 3,08)$, gayretli $(\% 3,08)$, hedefe odaklanır (\% 3,08), hayata hazırlar (\% 3,08), planlı (\% 3,08) olarak ortaya çıkmıştır.

Türkçe öğretmeni adaylarının ideal öğretmenin mesleki özelliklerine ilişkin bazı ifadeleri aşağıda verilmiştir:

İdeal öğretmen, öğrencilere gerekli olan bilgileri doğru ve etkili bir şekilde aktarmahdır. Doğru sözlü, adaletli bir kişiliği olmalıdır (ÖK4).

İdeal öğretmen mesleğini seven, kendini sürekli yenileyen ve öğrencilere dersi sevdirendir (ÖK5).

Yaşam boyu yeniliklere açık olan öğretmen ideal öğretmendir (ÖE4).

İdeal öğretmen, her şeyden önce mesleğini severek yapmahdır. İdeal öğretmenliğin en temel noktası budur. Çünkü mesleğini severse hem öğrenci hem kendi hem de toplum için en faydah kişi olur (ÖK5).

İdeal öğretmen Türkçe öğretmenim özellikleri neşeli derse canllhk katan öğrencileri derste aktif kllan, dersine gereken önemi veren, dersi hayatla bağdaşttran öğretmenedir (ÖE5).

Türkçe öğretmeni adaylarından elde edilen bulgulardan örnek alma özellikler temasına ilişkin kodlar Tablo 5'te gösterilmiştir.

Tablo 5. İdeal öğretmenin örnek alma temasına ilişkin kodlar

\begin{tabular}{llll}
\hline Tema & Kodlar & f & \% \\
& orta okuldaki Türkçe öğretmenim & 50 & 38,46 \\
Örnek olma & ilkokul öğretmenim & 30 & 23,08 \\
& annem & 24 & 18,46 \\
& Atatürk & 16 & 12,31 \\
\hline
\end{tabular}

Türkçe öğretmeni adaylarının ifadelerine göre ideal öğretmenin örnek alma teması şu kodlardan oluşmuştur: Ortaokuldaki Türkçe öğretmenim (\% 38, 46), ilkokul öğretmenim (\% 23,08), annem (\% $18,46)$, Atatürk (\% 12,31), lisedeki edebiyat öğretmenim $(\%$ 7,69) olarak ortaya çıkmıştır.

Türkçe öğretmeni adaylarının ideal öğretmenin örnek alma durumuna ilişkin bazı ifadeleri aşağıda verilmiştir:

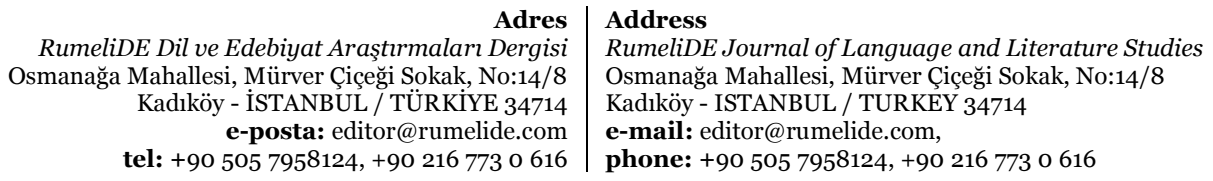


Bence ideal öğretmen Başöğretmen Mustafa Kemal Atatürk’tür (ÖK6).

Ortaokuldaki Türkçe öğretmenim ideal bir öğretmendi (ÖK7).

Bana göre ideal öğretmen annemdir, öğrencilerinin yani biz çocuklarının eksikliklerini bilir ona göre tamamlamaya çalışır, bizlere yaparak yaşayarak öğretir (ÖK8).

İdeal bir öğretmen benim gözümde Türkçe öğretmenim, ideal özellikleri, etkili, disiplinli bir düsüncesi var. Yaratıc fikirleri var ve bunu öğrencilere yansitıyor. Alanında her türlü beceriye sahip bir öğretmen (ÖK9).

Türkçe öğretmeni adaylarından elde edilen bulgulardan iletişim temasına ilişkin kodlar Tablo 6'da gösterilmiştir.

Tablo 6. İdeal öğretmenin iletişim temasına ilişkin kodlar

\begin{tabular}{llll}
\hline Tema & Kodlar & f & \% \\
İletişim & herkesle iyi iletişim kurar & 19 & 14,62 \\
& öğrencilerle iyi iletişim kurar & 9 & 6,92 \\
& ebeveynlerle iyi iletişim kurar & 7 & 5,38 \\
& meslektaşlarıyla iyi iletişim kurar & 6 & 4,62 \\
\hline
\end{tabular}

Türkçe öğretmeni adaylarının ifadelerine göre ideal öğretmenin iletişim özellikleri şu kodlardan oluşmuştur: herkesle iyi iletişim kurar (\% 14,62), öğrencilerle iyi iletişim kurar (\% 6,92), ebeveynlerle iyi iletişim kurar (\% 5,38), meslektaşlarıyla iyi iletişim kurar $(\% 4,62)$ olarak ortaya çlkmıştır.

Türkçe öğretmeni adaylarının ideal öğretmenin iletişim durumuna ilişkin bazı ifadeleri aşağıda verilmiştir:

İdeal öğretmen, ebeveynlerle iyi bir iletişime sahip olmahdır (ÖKıo).

İdeal öğretmen, çocuklarla iletişim kurabilen bir birey olmahdır (ÖK11).

Öğrencilerin aileleri ile iyi ilişkiler kuran öğretmen ideal bir öğretmendir (ÖK12).

İdeal öğretmen işini hakkıyla yapan, öğrenciyle iletişimi iyi olan öğretmendir (ÖE6).

Türkçe öğretmeni adaylarından elde edilen bulgulardan öğretmenliğe hazır olma temasına ilişkin kodlar Tablo 7'de gösterilmiştir.

Tablo 7. Öğretmenliğe hazır olma temasına ilişkin kodlar

\begin{tabular}{llll}
\hline Tema & Kodlar & $\mathbf{N}$ & $\mathbf{\%}$ \\
Öğretmenliğe Hazır Olma & Hazır & 60 & 46,15 \\
& Kendimi geliştirmeliyim & 32 & 24,62 \\
& Eksik ve yetersiz & 28 & 21,54 \\
& Tedirgin & 10 & 7,69 \\
\hline
\end{tabular}


Türkçe öğretmeni adaylarının ifadelerine göre Türkçe öğretmeni adaylarının öğretmenliğe hazır olma teması şu kodlardan oluşmuştur: hazır (\% 46,15), kendimi geliştirmeliyim (\% 24,62), eksik ve yetersiz $(\% 21,54)$, tedirgin $(\% 7,69)$ olarak ortaya çıkmıştır.

Türkçe öğretmeni adaylarının öğretmenliğe hazır olma durumuna ilişkin bazı ifadeleri aşağıda verilmiştir:

Kendimi mesleğe hazır hissediyorum çünkü öğretmenlik için yapılması gereken her şeyi en iyi şekilde tamamladığımı düşünüyorum (ÖE6).

Türkçe dersini, öğretmenliği, öğrencileri ve insanlarm hayatına dokunmayı seviyorum, kendimi öğretmenliğe hazır hissediyorum ve bir an önce öğrencilerime kavuşmak istiyorum (ÖK13).

Öğretmenliğe hazır olduğumu düşünüyorum çünkü kendimi alanımla ilgili donattım (ÖE7).

Öğretmenlik mesleği kutsal bir meslektir. Bende aldiğım eğitim sayesinde kendimi öğretmenlik mesleğine hazır hissediyorum. Çünkü her geçen gün var olan bilgilerinin üzerine yeni bilgiler katarak kendimi geliştirmeye devam ediyorum (ÖK14).

Şu an hazır değilim kendimi biraz daha geliştirmeliyim (ÖE8).

Öğretmenlik mesleğini seviyorum ama mesleğimi hakkıyla yapmak için kendimi tam hazır hissetmiyorum (ÖE9).

Kendimi mesleğe şuan için tam hazır olarak görmemekteyim. Bu mesleği en iyi şekilde yapmak için yüz yüze ve uygulamah eğitim almamı gerekiyor. Ayn zamanda alanım ile ilgili gereken eğitimlerin tamamlanması gerekiyor (ÖE1O) .

\section{Tartışma, sonuç ve öneriler}

Türkçe öğretmeni adaylarının ideal öğretmen algılarını ortaya koyup onlarda bu bağlamda bir bilinç oluşmaya katkıda bulunmayı amaçlayan bu araştırmaya katılan öğretmen adaylarından elde edilen verilerden ideal öğretmenin kişilik özellikleri, mesleki özellikleri, iletişim özellikleri, örnek alma ve öğretmenliğe hazır olma temaları ortaya çıkmıştır. Türkçe öğretmeni adaylarına göre ideal öğretmen öğrenmeye açı, anlayışlı, dost, idealist, empatik, güvenilen, neşeli, adanmış, ahlaklı, azimli, değer veren, demokratik, dinleyen, doğru sözlü, kültürlü, hoşgörülü, mütevazı, özgüven sahibi, sabırl, sevgi dolu ve tutarlı olmalıdır. Bu durum Köse ve Demir (2014) tarafından yapılan araştırmanın sonuçlarıyla örtüşmekte olup öğrencilerin öğretmenlerin alan bilgilerinden ziyade kişiliklerini vurguladıkları ifade edilmiştir.

Türkçe öğretmeni adaylarına göre ideal öğretmen adil, alanına hâkim, mesleğini seven, hayatı öğreten, disiplinli, notla tehdit etmeyen, donanımlı, teknolojiye hâkim, demokratik, rehber, etkili ve verimli ders yapan, sorgulamayı öğreten, değerleri önemseyen, faydalı insan yetiştiren, fazla yük yüklemeyen, fırsat veren, gayretli, hedefe odaklanan, hayata hazırlayan ve planlı olmalıdır. Bu sonuçlar Proctor, Clarke ve Mygdal (1989), Çalışkan, Negiş-Işık ve Saygın (2013), Çulha Özbaş ve Aktekin (2013) ile Bangir Alpan, Demirkan, Koç Erdamar, Yazçayır, ve Saraçoğlu (2019) tarafından yapılan araştırma sonuçlarıyla örtüşmektedir.

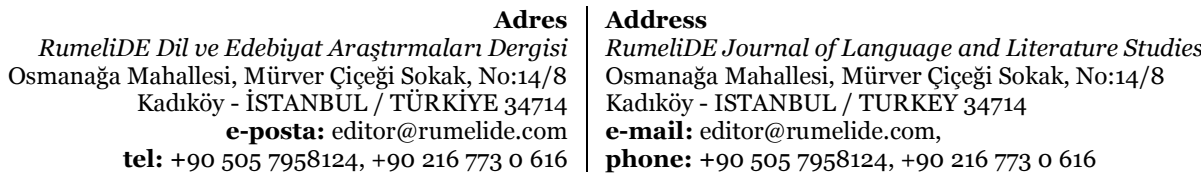


Türkçe öğretmeni adayları ortaokuldaki Türkçe öğretmenlerini, ilkokul öğretmenlerini, annelerini, başöğretmen Atatürk'ü ve lisedeki edebiyat öğretmenlerini ideal öğretmen olarak örnek aldıklarını belirtmişlerdir. Unutulmamalıdır ki öğretmenler ülkenin kalkınıp zenginleşmesinde vatandaşların sosyalleşip yaşama hazırlanmalarında, sosyal değerlerin nesillere aktarılmasında, kişilerin sahip oldukları düşünce sistemi ve dünyayı algıma şekillerinin belirlenmesinde (Karaboğa, 2019) önemli bir rol oynamaktadırlar.

Türkçe öğretmeni adaylarına göre ideal öğretmen herkesle öğrencilerle ebeveynlerle ve meslektaşlarıyla iyi iletişim kurandır. Yani ideal öğretmenin iletişim becerisi yüksek olmalıdır. Türkçe öğretmeni adaylarının büyük çoğunluğu kendilerini öğretmenliğe hazır görmektedirler. Türkçe öğretmeni adaylarının bir kısmı kendilerini geliştirmelerinin gerektiğini ifade ederken, bir kısmı kendilerini eksik ve yetersiz bulduklarını ve bir kısmı da yüz yüze uygulama yapamadıkları için tedirgin olduklarını belirtmişlerdir. Bu tedirginlik ve kendini mesleğe hazır görememe durumu birinci ve ikinci sınıflarda daha fazladır. Bu da doğal bir sonuçtur çünkü bu öğretmen adayları alanla ilgili derslerin daha başındadırlar ve zaman içerisinde derslerde yapılacak uygulamaların da etkisiyle kendilerini daha hazır hissedecekleridir. Türkçe öğretmeni adaylarının istenen düzeyde yetişmeleri için derslerin içeriklerinin düzenlenmesi, kullanılan yöntem ve tekniklerin doğru bir biçimde seçilip alan eğitimi ders içeriklerinin Türkçe öğretmenliğinin hedeflerine göre yapılandırılması (Durukan ve Maden, 2011, s.565) gerekmektedir.

Araştırmada elde edilen sonuçlar Türkçe öğretmeni adaylarının yarısına yakınının kendilerini mesleğe hazır olarak gördüklerini göstermiştir. Ancak öğretmen adaylarının diğer yarısı ise eksik, yetersiz, tedirgin ve kendilerini yetiştirmeleri gerektiğini belirtmişlerdir. Bu sonuç Ulusoy (2013) tarafından yapılan araştırma sonuçlarıyla örtüşmektedir. Öğretmen adayları bu konuda belli bir bilince sahiptirler ancak öğretmen adaylarının daha etkin olarak yetişmeleri için öğretmen yetiştiren kurumların da bu konudaki görevlerini en iyi şekilde yapmaları (Çulha Özbaş ve Aktekin, 2013, s.224) büyük önem taşımaktadır.

Türkçe öğretmeni adaylarının ideal öğretmen algıları onların ideal öğretmenin kim olduğunu, özelliklerinin neler olduğunu bilmelerini ve kendilerini bu bağlamda yetiştirmelerini olumlu olarak etkileyecektir. Bu nedenle öğretmen adaylarının bu bilinçle yetiştirilmeleri hem kendileri hem de öğretmenlik mesleğini ve gelecek nesillerin kalitesinin artırılması bakımından önem taşımaktadır. Bundan sonra yapılacak araştırmalarda diğer branşlardaki öğretmen adaylarının ideal öğretmen algıları incelenebilir. Ayrıca yapılacak araştırmalarda ideal öğretmen olabilmek için neler yapılacağına ilişkin öğretmen adaylarının da görüşleri alınabilir.

\section{Kaynakça}

Ada, Ş., \& Küçükali, R. (2016). Türk eğitim sistemi ve okul yönetimi. Anı.

Atabek-Yiğit, E.., \& Balkan-Kıyıcı, F. (2019). Öğretmen Adaylarının Öğretmen Algısı. Muğla Sitkı Koçman Üniversitesi Ĕ̆itim Fakültesi Dergisi [MSKU Journal of Education], 6(1), 20-39. DOI: 10.21666/muefd.460666.

Bangir Alpan, G., Demirkan, Ö., Koç Erdamar, G., Yazçayır, N., \& Saraçoğlu, G. K. (2019). Pedagojik formasyon eğitimi sertifika programı öncesi ve sonrası öğretmen adaylarının ideal öğretmen algıları. Akdeniz Ĕ̆itim Araştırmaları Dergisi, 13(27), 204-218.

Başaran, İ. E. (2008). Türk eğitim sistemi ve okul yönetimi. Ekinoks.

Büyüköztürk, Ş., Çakmak, E. K., Akgün, Ö. E., Karadeniz, Ş., \& Demirel, F. (2019). Bilimsel araştırma yöntemleri. Pegem Akademi.

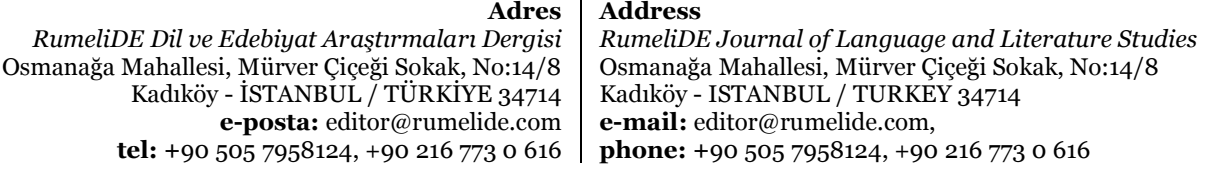


Cevizci, A. (2010). Ĕ̆itim sözlüğü. Say.

Çalışkan, M. Işık, A.N. \& Saygın, Y. (2013). Prospective Teachers' Perception of Ideal Teacher. İlköğretim Online, 12 (2), 575-584.

Çelikkaya, H. (2016). Eğitim bilimlerine giriş:(eğitimcilik ve öğretmenlik). Nobel Yayın Dağıtım.

Çulha Özbaş, B., \& Aktekin, S. (2013). Tarih öğretmen adaylarının tarih öğretmenliğine ilişkin inançlarının metafor analizi yoluyla incelenmesi. Journal of Theory \& Practice İn Education (Jtpe), 9(3).

Demirel, Ö. (2004). Öğretimde planlama ve değerlendirme öğretme sanatı. Pegem A.

Durukan, E., \& Maden, S. (2011). Türkçe öğretmeni adaylarının Türkçe öğretmenliği lisans programına yönelik görüşleri. Kastamonu Eğitim Dergisi, 19(2), 555-566.

Hocaoğlu, N., Baysal, E. (2019). Nicel araştırma modelleri-desenleri. G. Ocak (Ed.), Eğitimde araştırma yöntemleri (66-119. ss.). Pegem Akademi.

Karaboğa, M. T. (2019). Lise öğrencilerinin rol model tercihlerine ilişkin bir çalışma. Mersin Üniversitesi Ĕ̆itim Fakültesi Dergisi, 15(2), 363-391

Karagöz, Y. (2017). Bilimsel araştırma yöntemleri ve yayın etiği. Nobel Akademik.

Köse, M., \& Demir, E. (2014). Öğretmenlerin rol modelliği hakkında öğrenci görüşleri. International Journal of Social and Economic Sciences, 4(1), 08-18.

Maden, S., Durukan, E., \& Aslan, A. (2010). Türkçe öğretmeni adaylarının öğretmen niteliklerine yönelik görüşleri. Turkish Studies International Periodical For the Languages, Literatureand History of Turkish or Turkic.

Milli Ĕ̆itim Bakanlı̆̆ı. (2017). Öğretmenlik mesleği genel yeterlikleri. http://oygm.meb.gov.tr/meb_iys_dosyalar/2017_12/11115355_YYRETMENLYK_ MESLEYY_GENEL_YETERLYKLERY.pdf

TCCB Bilgi Sistemi (t.y.). Milli Eğitim Temel Kanunu, Erişim adresi https://www.mevzuat.gov.tr/MevzuatMetin/1.5.1739.pdf.

Öğretmen. (t.y.). Türk Dil Kurumu Sözlükleri. Erişim adresi https://sozluk.gov.tr

Özbaş, B. Ç., \& Aktekin, S. (2013). Tarih öğretmen adaylarının tarih öğretmenliğine ilişkin inançlarının metafor analizi yoluyla incelenmesi. Ĕ̆itimde kuram ve uygulama, 9(3), 211-228.

Özden, Y. (2011). Öğrenme ve öğretme. Pegem Akademi.

Proctor, T. J., Clarke, C. M., \& Mygdal, W. K. (1989). Teacher education students' perceptions of self and the ideal teacher. Educational Research Quarterly, 13(3), 44-52.

Sönmez, V., \& Alacapınar, F. (2019). Bilimsel araştırma yöntemleri. Anı.

Sünbül, A. M. (1996). Öğretmen niteliği ve öğretimdeki rolleri. Kuram ve Uygulamada Ĕ̆itim Yönetimi, 8(8), 597-608.

Şahin, A. E. (2011). Eğitimle ilgili temel kavramlar. V. Sönmez (Ed.), Eğitim bilimine giriş (1-24). Anı.

Şişman, M. (2008). Eğitim bilimine giriş (4. Baskı). Pegem Akademi.

Şişman, M. (2009). Öğretmen yeterlilikleri: Modern bir söylem ve retorik. İnönü üniversitesi eğitim fakültesi dergisi, $10(3), 63-82$.

Temizkan, M. (2008). Türkçe öğretmeni adaylarının öğretmenlik mesleğine yönelik tutumları üzerine bir araştırma. Journal of Turkish Educational Sciences, 6(3).

Ulusoy, M. (2013). Sınıf öğretmeni adaylarının ideal öğretmen ve mesleki yeterliklerle ilgili değerlendirmeleri. Uşak Üniversitesi Sosyal Bilimler Dergisi, 6(4).

Vassaf, B. H. (2011). Öğrenme yetersizliği. Alfa.

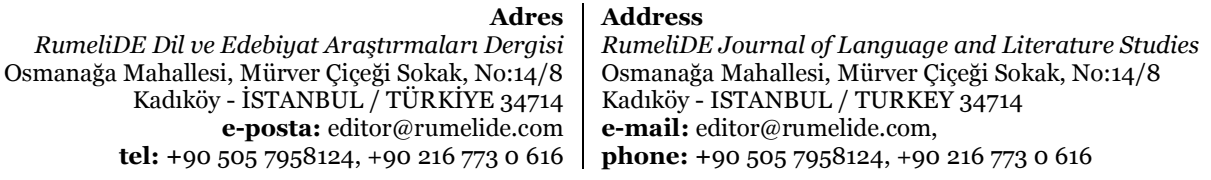


Yanpar-Yelken, T., Çelikkaleli, Ö., \& Çapri, B. (2007). Eğitim fakültesi kalite standartlarının belirlenmesine yönelik öğretmen adayı görüşleri (Mersin Üniversitesi örneği). Mersin Üniversitesi Eğitim Fakültesi Dergisi, 3(2), 191-215.

Yapıcı, Ş., \& Yapıcı, M. (2004). Öğretmen adaylarının okul deneyimi I dersine ilişkin görüşleri. İlköğretim Online, 3(2), 54-59.

Yüksek Öğretim Kurulu Başkanlığı (2018). Öğretmen yetiştirme lisans programları. https://www.yok.gov.tr/Documents/Kurumsal/egitim_ogretim_dairesi/Yeni-OgretmenYetistirme-Lisans-Programlari/AA_Sunus_\%20Onsoz_Uygulama_Yonergesi.pdf 